Niepełnosprawność. Dyskursy pedagogiki specjalnej

\author{
Agnieszka Sakowicz-Boboryko, Dorota Wyrzykowska-Koda, \\ Dorota Otapowicz \\ Uniwersytet w Białymstoku
}

\title{
Wartość edukacji w życiu studentów pełnosprawnych oraz studentów z niepełnosprawnością
}

W artykule zaprezentowano badania mające na celu poznanie wartości edukacji w życiu studentów z niepełnosprawnością w określonych obszarach w kontekście wybranych uwarunkowań socjodemograficznych oraz w odniesieniu do studentów pełnosprawnych. Badania przeprowadzono z wykorzystaniem metody sondażu diagnostycznego, której przyporządkowano technikę ankiety. Uzyskane wyniki wykazały, iż studenci z niepełnosprawnością przypisują edukacji znacznie wyższą wartość niż studenci pełnosprawni, szczególnie w wymiarze uzyskania niezależności życiowej. Obie grupy w podobnym stopniu oceniają swoją jakość funkcjonowania edukacyjnego. Występują również różnice w ocenie wartości edukacji studentów z niepełnosprawnością ze względu na ich płeć, miejsce zamieszkania i rodzaj dysfunkcji rozwojowej.

Słowa kluczowe: edukacja, wartość, niepełnosprawność

\section{The value of education in the lives of disabled and able-bodied students}

In the article researches were presented which aim is to realize how important education is in the life of disabled students in specific areas, in the context of selected sociodemographic conditions and considering able-bodied students. The researches were based on survey technique. The results showed that disabled students assign a much more value to independence of life than ablebodies students. Both groups evaluate the quality of educational functioning in the similar way. There are differencies in valuation of the worth of education of disabled students considering their sex, place of residence and kind of developmental disfunction.

Keywords: education, value, disability

\section{Wprowadzenie}

Wartością jest wszystko to, co dla człowieka przedstawia się jako ważne i cenne w co chce angażować swe wysiłki i wolę. Wartości stają się punktem odniesienia dla oceny tego, co jest dobre lub złe, ważne czy nieważne. Dzięki nim określamy 
swój stosunek do innych ludzi, rzeczy i zjawisk [Łobocki 2004]. Zakłada się, że wartości zorganizowane są w system ukierunkowujący i sterujący zachowaniem ludzi. Integrują postawy człowieka, determinują sposób postrzegania różnych przedmiotów, a stopień w jakim je sobie przypisuje, rzutują na jego samoocenę. Zdaniem Janusza Homplewicza [1996] to dążenie ku wartościom kształtuje człowieka, jest też w stanie przesądzać o jego wewnętrznym rozwoju, o jego przeżyciach, działaniach i całej postawie życiowej.

Kształtowanie indywidualnego systemu wartości odbywa się w płaszczyźnie wewnętrznych doświadczeń w procesie rozwoju osoby na poszczególnych etapach jej życia. Racjonalnie ukształtowany system wartości urasta zaś do podstawy tożsamości oraz fundamentu zdrowia i autokracji [za: Gaś 2001].

Edukacja jako proces kształcenia i wychowania efektywnie służy wielostronnemu rozwojowi, gdy staje się procesem integracji wokół wartości. Jest to możliwe wówczas, gdy wartości przenikają i dopełniają treści kształcenia. Józef Półturzycki [2014] trafnie zauważa, że wykształcenie w dobie edukacji ustawicznej staje się nie tylko podstawową, ale także stałą wartością zgodnie z zasadą "uczyć się, by być" i wiąże się, z obserwowanym w ostatnich dekadach w Polsce, wzrostem aspiracji edukacyjnych społeczeństwa.

Edukacja, będąc gwarantem kompetencji, umiejętności i wiedzy, ma szczególne znaczenie $\mathrm{w}$ przypadku osób z niepełnosprawnością [Chrzanowska 2010]. Poziom wykształcenia staje się dla nich istotnym wskaźnikiem oraz regulatorem zakresu uczestnictwa w życiu społecznym. Stanowi warunek zaistnienia na rynku pracy, charakteryzującym się coraz bardziej wzrastającą konkurencyjnością. Możliwość wylegitymowania się właściwymi kwalifikacjami jest podstawą do uzyskania zatrudnienia, zaś zatrudnienie dla osoby z niepełnosprawnością, zgodne z jej możliwościami, predyspozycjami i zainteresowaniami to nie tylko sposób na niezależność finansową i polepszenie sytuacji ekonomicznej, ale także niezbędny warunek poczucia własnej wartości i integracji ze społeczeństwem. Edukacja zmierzająca do wyposażenia osoby z niepełnosprawnością $\mathrm{w}$ określony zasób wiadomości i umiejętności jest pierwszym i podstawowym ogniwem rehabilitacji społecznej i zawodowej [Stochmiałek 2002], zapewnia jej poczucie niezależności i autonomii w społecznym funkcjonowaniu.

\section{Cel, metody badań}

Celem podjętych badań była próba odpowiedzi na następujące pytania problemowe:

1. Jakie znaczenie edukacji nadają studenci z niepełnosprawnością? Jak oceniają jej wartość w perspektywie szansy rozwoju, zdobycia niezależności życiowej, 
odpowiedniego statusu społecznego, poszukiwania nowych możliwości rozwoju, aktywizacji i integracji społecznej?

2. Czy i jakie różnice w ocenie wartości edukacji występują między studentami z niepełnosprawnością i studentami pełnosprawnymi?

3. Czy i w jakim zakresie zmienne socjodemograficzne (płeć, rodzaj niepełnosprawności, miejsce zamieszkania) różnicują wartość, jaką edukacji przypisują studenci z niepełnosprawnością?

Badania przeprowadzono z wykorzystaniem metody sondażu diagnostycznego. Zastosowano kwestionariusz ankiety, w którym zawarto obszary dążeń studentów w zakresie: szans życiowych, niezależności życiowej, odpowiedniego statusu społecznego, poszukiwania nowych perspektyw rozwoju, aktywizacji i integracji społecznej. Badani dokonali oceny znaczenia edukacji w każdym z obszarów oraz ogólnej oceny wartości edukacji w systemie ich wartości za pomocą pięciostopniowej skali (1 - znikome, 2 - niskie, 3 - dość duże, 4 - duże, 5 - bardzo duże). Studenci ocenili także jakość własnego funkcjonowania edukacyjnego w następujących kategoriach: szanse edukacyjne, starania edukacyjne, oczekiwania co do pomyślnej przyszłości edukacyjnej oraz satysfakcja z aktualnych wartości edukacyjnych - w skali pięciostopniowej (1 - bardzo źle, 2 - raczej źle, 3 - dość dobrze, 4 - dobrze, 5 - bardzo dobrze).

Materiał do badań zebrano na przełomie kwietnia i maja 2016 roku za pośrednictwem Internetu, wykorzystując portale internetowe: www.docs.google.com, www.fb.com.

W badaniach uczestniczyły 62 osoby, $w$ tym taka sama liczba studentów z niepełnosprawnością (grupa badana) i studentów pełnosprawnych (grupa kontrolna). W badanej grupie studentów największy odsetek stanowiły osoby przewlekle chore $(45,1 \%)$. Kolejne, pod względem wielkości, były zbiorowości studentów z niepełnosprawnością wzrokową i ruchową (po 19,4\%). Nieco mniejsza była liczba osób z wadą słuchu $(16,1 \%)$. W obu grupach (badanej i porównawczej) średnia wieku wynosiła 24 lata, przeważającą większość stanowiły kobiety (77\% ogółu osób z niepełnosprawnością, 87\% ogółu osób pełnosprawnych). Zarówno wśród studentów z dysfunkcją rozwojową $(81 \%)$, jak i studentów pełnosprawnych $(68 \%)$ dominowali mieszkańcy miast.

\section{Wyniki badań}

Z ogólnych obliczeń (rys. 1) wynika, iż edukacji nieco większą wartość przypisują studenci $\mathrm{z}$ niepełnosprawnością $(\mathrm{M}=3,73)$ niż studenci pełnosprawni $(\mathrm{M}=3,54)$. Ten stan rzeczy ma odniesienie do wszystkich analizowanych wymia- 
rów edukacji, czyli jako szansy rozwoju, zdobycia niezależności życiowej, odpowiedniego statusu społecznego, a także poszukiwania nowych perspektyw rozwoju, aktywizacji społecznej i integracji. W grupie badanych studentów średnie ocen w każdej kategorii wynoszą powyżej 3,6. Wartości tej nie przekracza natomiast większość wyników uzyskanych w grupie studentów pełnosprawnych. Wyjątek stanowi średnia odnotowana $w$ obszarze edukacji rozpatrywanej w perspektywie niezależności życiowej $(\mathrm{M}=3,91)$. Jest to, podobnie jak $\mathrm{w}$ grupie studentów z niepełnosprawnością $(\mathrm{M}=4,22)$, ten wymiar edukacji, któremu studenci nadają największe znaczenie.

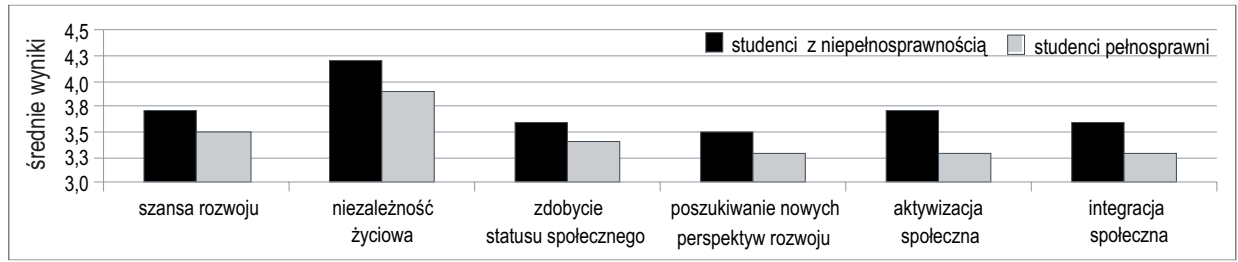

Rysunek 1. Ogólne średnie oceny wartości edukacji studentów z niepełnosprawnością i studentów pełnosprawnych

Źródło: Opracowanie własne.

Przeprowadzona analiza dowodzi, iż wszyscy studenci, niezależnie od stanu zdrowia, uznają ważność edukacji dla rozwoju człowieka, przy czym fakt ten bardziej akcentowany jest przez osoby z niepełnosprawnością $(M=4,11)$ niż pełnosprawne $(\mathrm{M}=3,64)$. Swoje stanowisko uzasadniają $\mathrm{m}$.in. następującymi argumentami: "edukacja daje podstawy do dalszej pracy nad soba", "stwarza możliwości nabierania doświadczenia, uzupetnia braki człowieka”, "pokazuje kierunek przyszłości człowieka" ,,,dzięki niej czlowiek jest w stanie konstruować swoje poglady". Uważna analiza pozwala dostrzec również pewne różnice między obiema grupami w zakresie interpretacji walorów (wyznaczników ważności) edukacji. Studentów pełnosprawnych cechuje zdecydowanie pragmatyczne podejście do edukacji: przypisują jej ważne miejsce $w$ dążeniu do realizacji własnych celów życiowych, w zdobyciu pracy zawodowej oraz $\mathrm{w}$ zapewnieniu lepszego bytu. $Z$ kolei dla studentów $\mathrm{z}$ niepełnosprawnością edukacja stanowi przede wszystkim szansę na samorealizację, przezwyciężenie własnych słabości i ograniczeń: „edukacja jest potrzebna do zdobycia samodzielności", "dzięki niej poszerzam swoje horyzonty”, "edukacja jest bardzo ważna, gdyż pozwala mi dostrzec moja wartośc”", „bez wyksztatcenia jestem nikim".

Prezentowane stanowisko koresponduje z wypowiedziami studentów na pytanie: W jaki sposób edukacja jest w stanie poprawić Twoją sytuacje życiową? Ze strony studentów z niepełnosprawnością często padały odpowiedzi typu: „dzięki niej zdobywam wiedzę, do której sama bym nie dotarła”, "edukacja podniesie moja samoocenę", 
"dzięki niej mam wyższe poczucie własnej wartości". Pojawiały się również, tak jak w przypadku osób pełnosprawnych, sformułowania natury egzystencjalnej odwołujące się do najbliższej przyszłości, aczkolwiek, co należy podkreślić, zawsze przedstawiane w kontekście niepełnosprawności, np.: „liczę, że po ukończeniu studiów znajdę dobra pracę, wyprowadzę się od rodziców i w końcu usamodzielnię się", "liczę na to, że niedtugo uda mi się znaleźć pracę, pomimo wtasnych niedyspozycji". W świetle powyższego istotne wydają się być dane (rys. 2), z których wynika, iż to studenci $\mathrm{z}$ niepełnosprawnością formułują większe oczekiwania $\mathrm{w}$ związku $\mathrm{z}$ ukończeniem studiów $(\mathrm{M}=3,72)$, a także podejmują większe starania w kierunku poszukiwania możliwości edukacji $(\mathrm{M}=3,64)$. W przypadku studentów z grupy porównawczej uzyskane rezultaty są niższe $\mathrm{i}$ wynoszą odpowiednio: $\mathrm{M}=3,48$ i $\mathrm{M}=3,34$.

Studentów poproszono również o ustosunkowanie się do problemu: $C z y$ edukacja jest dobrem cenionym w czasach wspótczesnych? Część badanych stoi na stanowisku, iż obecnie młodzi ludzie coraz częściej rezygnują z edukacji na rzecz aktywności zawodowej, ci zaś, którzy decydują się na studia wyższe czynią to wyłącznie $\mathrm{w}$ celu zdobycia kwalifikacji niezbędnych do podjęcia pracy. Zanotowano również głosy twierdzące, że wykształcenie wyższe wciąż nie daje gwarancji zatrudnienia, a tym bardziej życia na godnym poziomie. Również studenci prezentujący odmienne zdanie $\mathrm{w}$ tej kwestii wartość edukacji rozpatrują poprzez pryzmat aktywności zawodowej. W ich ocenie współcześnie „pracodawcy sq bardziej świadomi wagi tytułów, które posiadają ich pracownicy, bardziej ich doceniaja", co przekłada się na zwiększenie szans znalezienia pracy przez osoby z wykształceniem wyższym. Ponadto, jak twierdzą, , dzięki zdobytemu wykształceniu można założyć własną działalność, realizować się dzięki niej". Na podstawie przytaczanych argumentów można

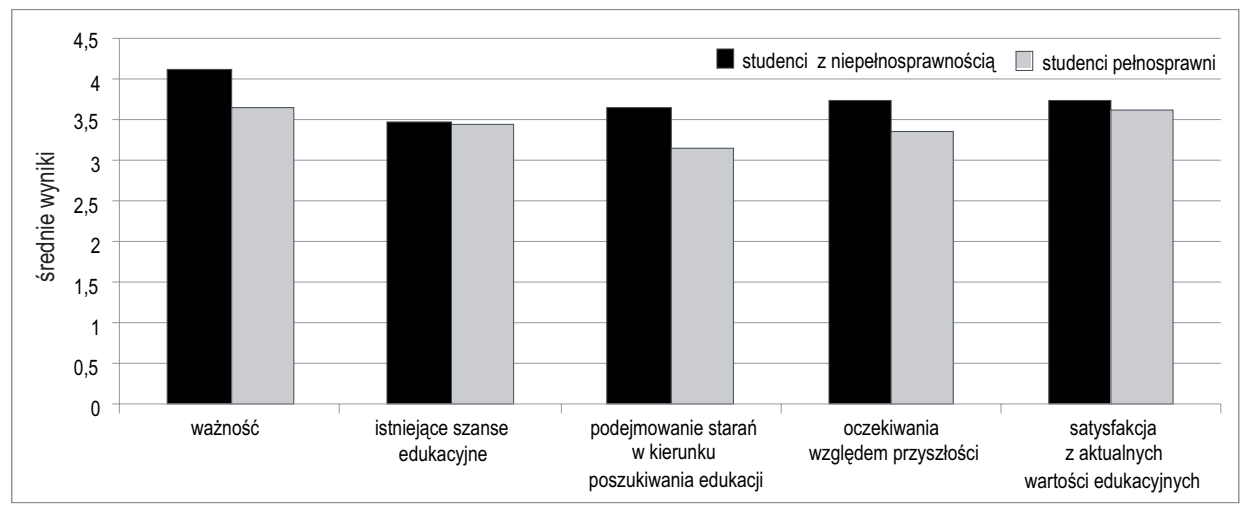

Rysunek 2. Kryteria oceny wartości edukacji studentów z niepełnosprawnością i studentów pełnosprawnych

Źródło: Opracowanie własne. 
odnieść wrażenie, że w opinii niektórych studentów edukacja jest dobrem cenionym przez pracodawców, niekoniecznie zaś przez samych pracowników.

W kolejnym kroku postępowania badawczego podjęto próbę sprawdzenia, czy występują różnice w ocenie wartości edukacji studentów z niepełnosprawnością ze względu na ich płeć, rodzaj dysfunkcji rozwojowej i miejsce zamieszkania.

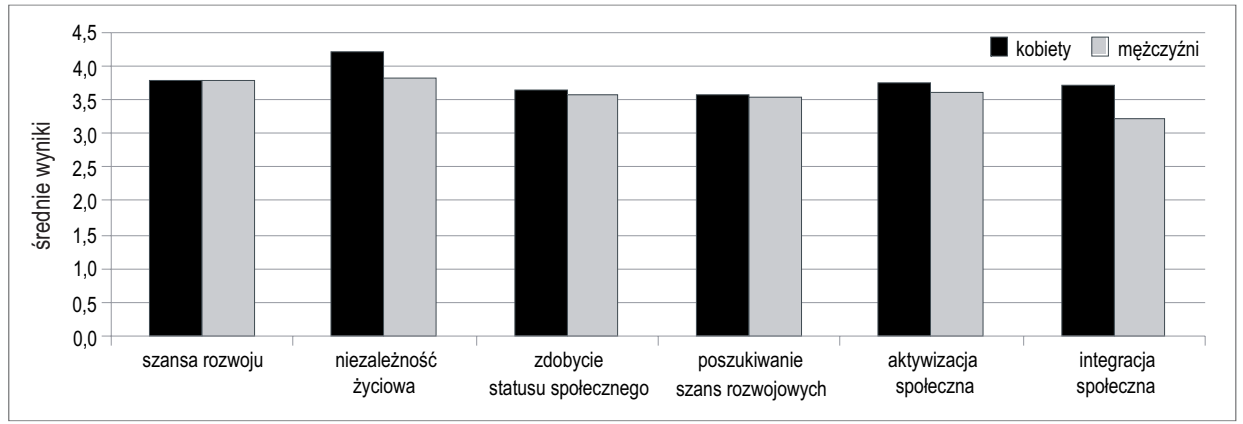

Rysunek 3. Średnie oceny wartości edukacji w podziale na płeć badanych studentów Źródło: Opracowanie własne.

Analiza danych w podziale na płeć badanych osób (rys. 3) wykazała, iż wartość edukacji nieco wyżej oceniają kobiety z niepełnosprawnością $(\mathrm{M}=3,76)$ niż niepełnosprawni mężczyźni $(M=3,49)$. Najwyższy wynik - $M=4,19$ - odnotowany $\mathrm{w}$ grupie kobiet dowodzi, iż upatrują $\mathrm{w}$ niej przede wszystkim szansy na zdobycie niezależności życiowej. Ponadto zdecydowanie bardziej niż niepełnosprawni studenci akcentują społeczny wymiar edukacji - jej znaczenie w zakresie aktywizacji społecznej, a zwłaszcza integracji. Natomiast w grupie mężczyzn zniepełnosprawnością ranga edukacji jako jednej z dróg naturalnego włączenia się w środowisko społeczne oceniana jest najniżej $(M=3,20)$. Średnie wyniki dla pozostałych analizowanych obszarów edukacji, tj. rozpatrywanej w perspektywie szans rozwoju, zdobycia niezależności życiowej, odpowiedniego statusu społecznego oraz poszukiwania nowych możliwości rozwoju sytuują się na podobnym poziomie: $\mathrm{w}$ przedziale 3,6-3,8.

Analiza wyników przeprowadzona ze względu na rodzaj niepełnosprawności badanych osób (rys. 4) wykazała, że ogólne średnie ocen otrzymane wśród studentów przewlekle chorych i z niepełnosprawnością wzrokową są takie same: $\mathrm{M}=3,80$. Niewiele niższy wynik uzyskano $\mathrm{w}$ grupie osób $\mathrm{z}$ niepełnosprawnością ruchową $(M=3,51)$. Natomiast najniższą rangę edukacji nadają studenci z niepełnosprawnością słuchową $(\mathrm{M}=2,08)$. W przeciwieństwie do pozostałych badanych osób sceptycznie oceniają jej znaczenie w każdym wymiarze, a w szczególności $\mathrm{w}$ zakresie stwarzania szans rozwoju, zgodnie $\mathrm{z}$ własnymi dążeniami, 
potrzebami i oczekiwaniami oraz jako drogi otwierającej perspektywy poszukiwania nowych możliwości rozwojowych. Równie krytycznie odnoszą się do znaczenia edukacji w kontekście integracji społecznej. Ten wymiar edukacji najwyżej oceniają zaś studenci z niepełnosprawnością ruchową $(\mathrm{M}=3,72)$. Jednakże, co należy wyraźnie podkreślić, podobnie jak osoby z wadą wzroku $(M=4,25)$ i przewlekle chore $(\mathrm{M}=4,16)$, największą wartość edukacji dostrzegają w możliwości zdobycia dzięki niej niezależności życiowej $(M=4,0)$. Równie wysoko oceniane jest znaczenie edukacji ujmowanej $w$ kategoriach: 1) szansy rozwoju (studenci przewlekle chorzy $-\mathrm{M}=4,0$ ) oraz 2 ) zdobycia kompetencji niezbędnych do poszukiwania nowych perspektyw rozwojowych (studenci z niepełnosprawnością wzrokową $-\mathrm{M}=4,0)$.

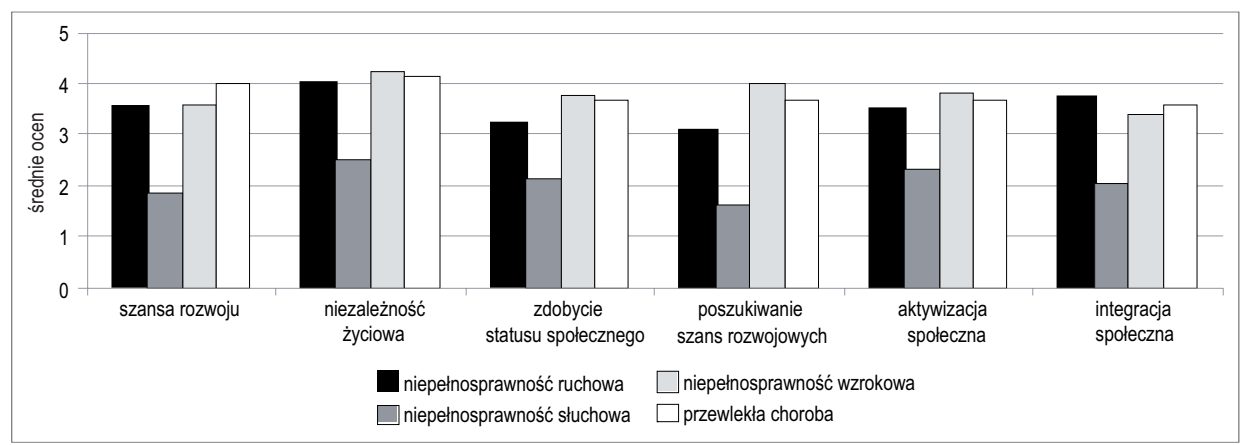

Rysunek 4. Średnie oceny wartości edukacji w podziale na rodzaj niepełnosprawności badanych studentów

Źródło: Opracowanie własne.

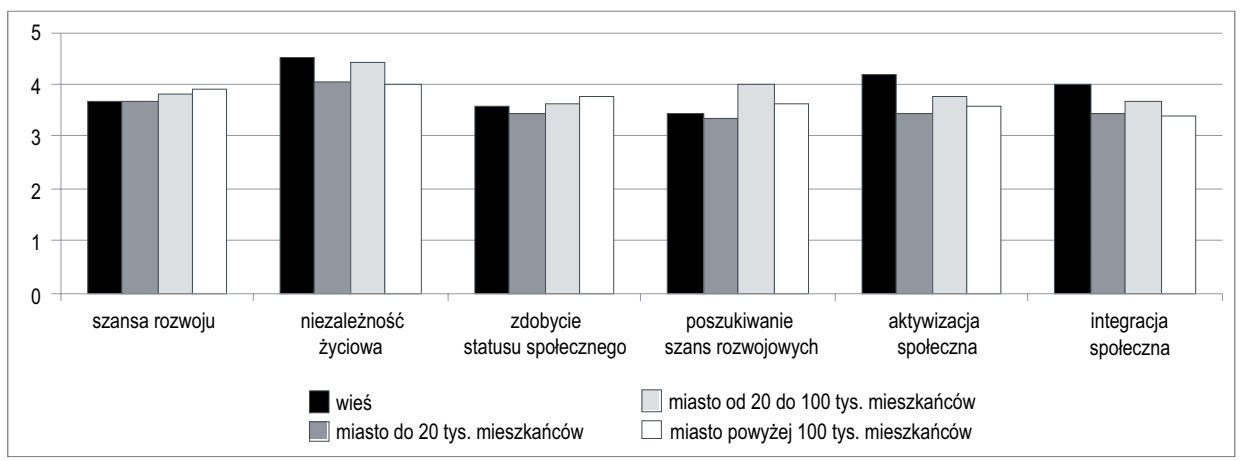

Rysunek 5. Średnie oceny wartości edukacji w podziale na miejsce zamieszkania badanych studentów

Źródło: Opracowanie własne. 
Rozkład ogólnych danych (rys.5) wskazuje na niewielkie różnice między studentami mieszkającymi w mieście $(\mathrm{M}=3,72)$ i na wsi $(\mathrm{M}=3,90)$ w zakresie oceny wartości nadawanej edukacji. Nieznaczne zróżnicowanie można zaobserwować również w obrębie grupy osób mieszkających w środowisku miejskim. Spośród nich najniższy średni wynik $(M=3,56)$ odnotowano dla studentów pochodzących z miast liczących do 20 tysięcy mieszkańców. Rezultaty uzyskane wśród pozostałych osób ze środowiska miejskiego są nieco wyższe i wynoszą odpowiednio: $\mathrm{M}=3,89-\mathrm{w}$ miastach liczących od 20 do 100 tysięcy oraz $\mathrm{M}=3,71$ - $\mathrm{w}$ środowisku wielkomiejskim (powyżej 100 tysięcy mieszkańców).

Analiza wyników badania ujawnia, iż niezależnie od miejsca zamieszkania badanych studentów znaczenie edukacji jest najbardziej przez nich dostrzegane w wymiarze zdobywania niezależności życiowej. $W$ każdym analizowanym środowisku otrzymana średnia wartość liczbowa jest co najmniej równa 4,0. Na ten aspekt edukacji uwagę zwracają w szczególności studenci pochodzący ze wsi oraz z miast liczących od 20 do 100 tysięcy mieszkańców. W przypadku osób ze środowiska wiejskiego wyraźnie zaznacza się również fakt eksponowania znaczenia edukacji w zakresie aktywizacji społecznej $(M=4,20)$ i integracji $(M=4,0)$. Z kolei osoby mieszkające $\mathrm{w}$ większych miastach cechuje zdecydowane nasilenie $\mathrm{w}$ kierunku ujmowania edukacji jako szansy rozwoju (studenci z miast liczących powyżej 100 tysięcy mieszkańców - M = 4,0), a także jako drogi otwierającej przed nimi możliwości poszukiwania nowych perspektyw rozwojowych (studenci z miast liczących od 20 do 100 tysięcy mieszkańców - M = 4,44). Przedstawiony stan rzeczy nie ma miejsca w przypadku pozostałych badanych studentów.

\section{Dyskusja wyników}

Uzyskane wyniki badań wskazują, że studenci z niepełnosprawnością przypisują dość duże znaczenie edukacji w swoim życiu. Średnie wyniki ocen przekraczają wartość 3,5, zbliżając się do wartości 4,0 - określającej duże znaczenie przypisywane edukacji w obszarze szans rozwoju, poprawy statusu społecznego, aktywizacji społecznej i integracji. Średnie wartości ocen studentów pełnosprawnych w tych samych obszarach przyjmują wartość 3,5 oraz poniżej, zbliżając się $\mathrm{w}$ kierunku ocen przeciętnych. Jedynie $\mathrm{w}$ obszarze niezależności życiowej obie grupy przypisały wyższe znaczenie edukacji: studenci pełnosprawni przypisywali dość duże znaczenie (średnia wartość ocen zbliżała się do 4,0), gdy studenci niepełnosprawni nadawali zdecydowanie duże znaczenie (średnia wartość ich ocen przekraczała 4,0). 
Można zatem zauważyć, że studenci z niepełnosprawnością przypisują edukacji wyższe znaczenie we wszystkich badanych obszarach w stosunku do studentów pełnosprawnych. Nadając duże znaczenie edukacji upatrują w niej swoich szans życiowych bardziej niż ich pełnosprawni rówieśnicy. Nic też dziwnego, że często wykazują znaczną determinację i ogromne zaangażowanie w pokonywanie wszelkich przeciwności, utrudnień, wytrwale kontynuując naukę [Otapowicz, Sakowicz-Boboryko, Bilewicz, Wyrzykowska-Koda 2016]. Znamienne jest także, że niektórzy ukrywają wręcz niepełnosprawność, rezygnując tym samym z pomocy i wsparcia, z którego mogliby skorzystać na rzecz podejmowania wyzwań i samodzielnego radzenia ze swoimi sprawami [Poltyn-Zaradna, Waszkiewicz, Zatońska 2009]. Wyższe wyniki ocen studentów z niepełnosprawnością może uzasadniać także fakt, że uczestnictwo w edukacji na poziomie wyższym ma dla nich dodatkowe znaczenie. Edukacja jest jedną z najlepszych form kompleksowej rehabilitacji, a w szczególności pozwala ujawniać potencjały, których nie dotknęła niepełnosprawność czy choroba [Żuraw 2014].

Jak wskazują prezentowane wypowiedzi badanych studentów z niepełnosprawnością, edukacja stanowi przede wszystkim szansę na samorealizację, przezwyciężenie własnych słabości i ograniczeń, podwyższenia własnej wartości. Wydaje się również, że studenci pełnosprawni mogą posiadać większe możliwości czerpania wartości z doświadczeń pozaedukacyjnych niż studenci z niepełnosprawnością. Możliwości praktycznego wykorzystywania nabytej wiedzy i umiejętności, $\mathrm{w}$ tym sprawdzania się $\mathrm{w}$ różnych sytuacjach życiowych, jest często podkreślaną potrzebą studentów. Ich oczekiwania wykraczają poza ramy oferowanego im programu edukacyjnego. Tymczasem studenci z niepełnosprawnością mogą być bardziej zdani na zorganizowany proces edukacyjny, w którym zawsze w jakimś stopniu mogą liczyć na niwelowanie barier i dostosowanie warunków do ich możliwości i potrzeb [Filek 2015].

Najwyższe znaczenie edukacji studenci przypisali w obszarze niezależności życiowej. Tu rodzi się pewne niebezpieczeństwo, na które wskazuje Hanna Żuraw [2014]. Zdaniem autorki w obliczu perspektywy braku zatrudnienia, konieczny jest realizm w ocenie jej znaczenia - sytuacja ta może bowiem prowadzić do poczucia nieprzydatności nie tylko wykształcenia, ale także nieprzydatności egzystencjalnej. Analiza wypowiedzi studentów wskazuje jednak, że niektóre osoby dostrzegają istniejące trudności na rynku pracy, a mimo to wyrażają nadzieję, że wykształcenie poprawi ich sytuację, choć nie stanowi ono gwarancji uzyskania pracy i życia na godnym poziomie.

Uzyskane rezultaty wykazały brak znaczących różnic w nadawaniu znaczenia edukacji przez badanych ze względu na ich płeć. Jednocześnie należy zauważyć, że kobiety bardziej niż niepełnosprawni mężczyźni akcentują społeczny wymiar edukacji oraz jej znaczenie w kontekście zdobywania niezależności życiowej. 
Wyraźne zróżnicowania ujawniły się przy uwzględnieniu rodzajów niepełnosprawności, przy czym szczególnie niskie znaczenie edukacji, we wszystkich jej obszarach, nadawane jest przez studentów z niepełnosprawnością słuchową. Średnie wyniki w tej grupie $(\mathrm{M}=2,08)$ wskazują na niską wartość przypisywaną edukacji, zwłaszcza $\mathrm{w}$ zakresie stwarzania szans rozwoju, zgodnie $\mathrm{z}$ własnymi dążeniami, potrzebami i oczekiwaniami oraz jako drogi otwierającej perspektywy poszukiwania nowych możliwości rozwojowych. Równie krytycznie odnoszą się do znaczenia edukacji w kontekście integracji społecznej. Trudności w dostępie do informacji osób z uszkodzonym słuchem są bardzo dotkliwe i często trudne do przezwyciężenia. Ponadto często stają się przyczyną odizolowania, osamotnienia i braku zrozumienia ze strony środowiska osób słyszących [Krakowiak, Krakowiak 2011].

Można zatem przypuszczać, iż doświadczanie owych negatywnych przeżyć również $\mathrm{w}$ przypadku badanych studentów z niepełnosprawnością słuchową może być jednym z powodów ich niskiej oceny znaczenia edukacji $\mathrm{w}$ zakresie własnego rozwoju i integracji społecznej. Wskazuje się, że osoby z niedosłuchem często odczuwają, iż w procesie edukacji nie są w pełni wykorzystywane ich możliwości intelektualne i uzdolnienia. Być może z tego też powodu niewiele osób niedosłyszących podejmuje się studiowania [Butkiewicz, Czajkowska-Kisil 2014].

Analiza ze względu na miejsce zamieszkania ujawnia, że wyższe - zdecydowanie duże - znaczenie edukacji nadają osoby mieszkające na wsi (w obszarze niezależności życiowej i aktywizacji). Wyniki pozostałych grup mieszczą się w granicach wartości dość dużej. Jedynie w zakresie niezależności życiowej zdecydowanie duże znaczenie edukacji przypisują także osoby mieszkające w miastach średniej wielkości.

Uzyskane wyniki oceny jakości funkcjonowania edukacyjnego studentów z niepełnosprawnością wskazują, że podobnie jak studenci pełnosprawni, dość dobrze oceniają swoje szanse edukacyjne, własne starania związane z poszukiwaniem możliwości edukacyjnych, oczekiwania co do pomyślnej przyszłości edukacyjnej, jak i satysfakcję z aktualnych wartości edukacyjnych. Wydaje się zatem, że podobnie, a nawet wyżej niż pełnosprawni studenci oceniają jakość własnego funkcjonowania w procesie edukacji. Jednak wyższe znaczenie nadawane edukacji może powodować, iż odczuwają oni mniejszą satysfakcję z jakości funkcjonowania edukacyjnego niż studenci pełnosprawni. Można zatem sądzić, że tym bardziej ocena jakości funkcjonowania w tym obszarze studentów z niepełnosprawnością nie wskazuje na doświadczanie przez nich szczególnych niedogodności czy barier w edukacji z tytułu posiadanych dysfunkcji rozwojowych. 


\section{Wnioski}

1. Studenci z niepełnosprawnością przypisują dość duże znaczenie edukacji w swoim życiu, bardziej niż studenci pełnosprawni doceniają jej wartość.

2. Studenci z niepełnosprawnością najwyższe (zdecydowanie duże) znaczenie edukacji dostrzegają w zakresie uzyskania niezależności życiowej.

3. Płeć nie jest czynnikiem różnicującym studentów z niepełnosprawnością w zakresie ogólnej oceny wartości edukacji, przy czym kobiety z niepełnosprawnością bardziej niż niepełnosprawni mężczyźni akcentują społeczny wymiar edukacji (znaczenie w zakresie aktywizacji społecznej i integracji) i jej znaczenie w osiąganiu niezależności życiowej.

4. Najniższe znaczenie edukacji nadają studenci z niepełnosprawnością słuchową.

5. Znaczenie edukacji w obszarze integracji społecznej najwyżej oceniane jest przez studentów z niepełnosprawnością ruchową.

6. Wartość edukacji w kontekście stwarzania szans rozwoju, zgodnie z własnymi dążeniami, potrzebami i oczekiwaniami oraz jako drogi otwierającej perspektywy poszukiwania nowych możliwości rozwojowych najbardziej dostrzegają studenci z niepełnosprawnością wzrokową.

7. Najwyższe (zdecydowanie duże) znaczenie edukacji nadają studenci z niepełnosprawnością mieszkający na wsi.

8. Studenci z niepełnosprawnością, podobnie jak studenci pełnosprawni, pozytywnie (dość dobrze) oceniają jakość swojego funkcjonowania edukacyjnego.

\section{Bibliografia}

Butkiewicz M, Czajkowska-Kisil M. (2014), Głusi i nie(do)styszący na uczelni wyższej [w:] Sytuacja osób głuchych w Polsce Raport Zespołu ds. g/Głuchych przy Rzeczniku Praw Obywatelskich, M. Świdziński (red.), Wydawnictwo Biuro Rzecznika Praw Obywatelskich, Warszawa, s. 28-35.

Chrzanowska I. (2010), Problemy edukacji dzieci i młodzieży z niepetnosprawnością. Regionalna specyfika czy ogólnopolska tendencja, Oficyna Wydawnicza „Impuls”, Kraków.

Denek K, Urbański-Korż R. (2001), Wartości edukacyjne cz. 1, Poznań, http://www.andragog.strefa.pl/strony/wartedcz1.htm [dostęp: 04.05.2017].

Filek J. (2015), Szkolnictwo wyższe wobec zjawiska niepetnosprawności. Od przełamywania barier do form wspótpracy międzyuczelnianej, „Studia Oeconomica Posnaniensia”, vol. 3, nr 10, s. 96-112.

Homplewicz J. (1996), Etyka pedagogiczna, Wydawnictwo Wyższej Szkoły Pedagogiczna, Rzeszów.

Krakowiak K., Krakowiak Ł (2011), Trudności niestyszących jako wyzwanie do odpowiedzialności i ustawicznego dialogu [w:] Student niestyszący we wspólnocie akademickiej. Informator o warunkach edukacji wyższej osób z uszkodzeniami stuchu, K. Krakowiak, R. Kołodziejczyk, A. Borowicz, E. Domagała-Zysk (red.), Wydawnictwo KUL, Lublin, s. 9-34. 
Łobocki M. (2004), Teoria wychowania w zarysie, Oficyna Wydawnicza „Impuls”, Kraków.

Otapowicz D, Sakowicz-Boboryko A, Bilewicz M., Wyrzykowska-Koda D. (2016), Autonomia osób z niepetnosprawnościa, Wydawnictwo Trans Humana, Białystok.

Poltyn-Zaradna K, Waszkiewicz L, Zatonska K. (2009), Dlaczego niepetnosprawny student jest "niewidoczny"? „Problemy Higieny i Epidemiologii”, vol. 90(3), s. 374-377.

Półturzycki J. (2014), Niepokój o dydaktykę, Wydawnictwo Naukowe Instytutu Technologii Eksploatacji Państwowy Instytut Badawczy, Warszawa-Radom, s.14.

Stochmiałek J. (2002), Edukacja i zatrudnienie osób niepełnosprawnych w krajowej i europejskiej polityce społecznej [w:] Pedagogika specjalna szansa na realizację potrzeb z odchyleniami od normy, W. Dykcik, Cz. Kosakowski, J. Kuczyńska-Kwapisz (red.), Wydawnictwo Naukowe Polskiego Towarzystwa Pedagogicznego Oddział w Poznaniu, Olsztyn-WarszawaPoznań, s. 55-67.

Żuraw H. (2014), Studenci niepetnosprawni doby ponowoczesności w Polsce [w:] Student Niepetnosprawny. Szkice i Rozprawy, A. Zacharuk (red.), Wydawnictwo Uniwersytetu Przyrodniczo-Humanistycznego w Siedlcach, Siedlce, s. 69-90. 